\title{
The Comparison of Affixes in Minangkabau Language Between the Region of Origin and Migration Region
}

\author{
Noviatri $^{1}$, Reniwati $^{2}$ \\ $\left\{{ }^{1}\right.$ noviatri@hum.unand.ac.id, ${ }^{2}$ reniwati@hum.unand.ac.id $\}$ \\ ${ }^{1,2}$ Andalas University Padang, Indonesia
}

\begin{abstract}
This article aims to describe the similarities and differences found in Minangkabau language in Limapuluh Kota (Rao-Rao and Simalanggang), West Sumatra with Kampar Riau rantau (Kuok and Patapahan). The scope of this study is under dialectology field. Language units that are compared are affixes. The method used in providing the data are, first interviewing with eliciting as the basic technique and interviewing, recording and note taking as advance technique. In analyzing the data, the articulatory and translational identity methods are used with dividing key factors as the basic technique and differentiating and equalizing techniques as the advance technique. The method applied in presenting the results of the analysis isinformal methods. The results of analysis show that there are similarities and differences in the form and use of affixes between Minangkabau language in the origin of area and Minangkabau language in migration area.
\end{abstract}

Keywords: Affixes, Dialectology, Minangkabau, Area of Origin, Migration Area

\section{INTRODUCTION}

According to Ramlan [1], affix is a grammatical bound unit which in a word is an element that is not a word and not a main word, which has the ability to attach to other units to form words or new main words. Chaer [2] named affixes as affix morphemes, namely morphemes that cannot be the basis for word formation, but become forming elements in the affixation process. Zainal and Junaiyah [3] states that affixes have very important role because the presence of affixes on a basic word can change the form, function, and meaning of the word attached to it. The process of adding affixes to the basic word is called affixation. This affix according to Zainal and Junaiyah [3] is divided into four types, namely prefixes, suffixes, confixes, and joining affixes. The studies on affixes have been carried out by a number of previous researchers. In his article entitled "Derivational Affixes of Minangkabau Language Kamang Magek Dialect", Zeli [4] examines the types of derivational affixes, the process of derivational affixes formation, and the meaning of derivational affixes. In the data analysis, it is stated that there are several types of derivational affixes, such as, affixes $m a-, t a-, b a-a n$, and $\mathrm{ka}-\mathrm{an}$. Based on its meaning, there are several meanings of derivational affixes, such as the most and process. Next, Rahmadhana [5] also examines prefixes in Minangkabau Language of Agam dialect. The study concludes that morphologically affixes in Minangkabau language has function to form verbs and nouns.

Comparative studies have also been done before. Noviatri [6] makes a comparison of affix -an in Indonesian and Minangkabau languages. In his article, the differences in affix -an in the 
two languages are examined. The conclusion is the function of affix -an in Minangkabau language is to form verbs. Meanwhile, in Indonesian, affix -an function to form nouns. The comparison between isolect in the area of origin with migration area (rantau) can be seen from the article written by Jaafar [7] in Gema Online journal which examines morphosyntax of Negeri Sembilan dialect and Minangkabau dialect. He slightly talks about affixes, but limited to prefixes and some joining affixes only. In the analysis, it is explained that there are differences between the prefix and joining affixes of Minangkabau dialect in Negeri Sembilan with Minangkabau dialect in the origin of area. The comparison of isolect between the area of originwith migration area (rantau) have also been carried out by Noviatri [8]. The article of this research is published in Arbitrer journal. In that paper, the researcher discusses the comparison of the use of affixes in Minangkabau language originated from Pasaman and Rao with the Rokan Riau as migration area. The study concluded that there are some differences and similarities in the use of affixes between the origin area and migration area. A study about the comparison of isolect between the origin of area and migration area can also be found in article written by Reniwati [9] and Aslinda [10]. However, the units being compared are lexicons and sounds.

Another study on affixes is written by Yusdi [11] which examines affixes ter- in Indonesian language. He discusses the forms, functions and meaning of the affixes ter- in Indonesian. Based on the form, affix ter- can be joined to several basic words. Based on the function, affix ter- can formed transitive and intransitive verbs. Based on the meaning, this prefix has several meanings. Furthermore, Indra [12] examines the errors of the uses of affixation in Indonesian Language found in the writing of elementary school students in Agam District, West Sumatra. The error in the use of affixes covered, 1) basic form selection errors, selection of prefixes, addition of prefixes, and deletion of prefixes; 2) the error in adding and deleting suffixes; and 3) the error in the use of confixes includes misuse of the basic form on the word which has prefix and suffix (confixes), confix selection errors, confix addition error, and confix deletion error. Other authors, Kulsum [13] review suffixes -is, -ik, and -its in English. Similar to Yusdi [11], Kulsum [13] also examines forms, functions, meanings, and formulas. The results of the study are not much different from Yusdi [11].

Some of the previous studies were done descriptively andsome others are in form of comparative study. For the comparative studies there have been no studies or writings that compare the affixes in Simalanggang and Rao-Rao West Sumatra with the affixes in migration area particularly in Kuok and Patapahan Riau. Therefore, this research is very important to be carried out to examine the differences and similarities in the use of affixes isolect in the two regions. The purpose of the study is to describe and explain the differences and similarities in the form and the use of affixes in Minangkabau language in the two regions.

This comparative study of affixes includes in the study of dialectology. Francis in Nadra [14] states that dialectology is the study of variations in language used by a small group of speakers of a language. Nadra [14] in another section states that, these variations are seen in elements of language. One of language element that shows the variation is morphological elements, exactly the affixes.

\section{RESEARCH METHOD}

The method applied in this research is the method proposed by Sudaryanto [15]. The researcher applied interviewing method in providing the data. This method is followed up with a set of techniques, namely basic techniques and advanced techniques. The basic technique is eliciting technique, while the advanced technique is interviewing technique, recording, and 
note taking. Basically, this method is applied by having direct conversation between the researcher and the informant. When the conversation takes place the researcher records and take a note to the answers given by the informant.

The data are taken in Limapuluh Kota Districts, exactly in Nagari Rao-Rao and Simalanggang. This place is taken as a sample of the research area because both of these area (Rao-Rao and Kampar Riau) have a historical link.

In analyzing the data, translational and articulatory identity methods are applied. The basic technique used is segmenting key factor. The advanced technique is differentiating technique and equalizing technique. The function of this technique is to find out the differences and similarities of the forms and affixes that are used in the region of origin and the migration region.

\section{RESULT AND DISCUSSION}

This section will explain the comparison of the morphological variations of the Minangkabau language from the region of origin and migration region. The elements being compared are the Minangkabau language affixes used between the observation points (OP) of the origin area and the observation point in migration area. OP of the origin area is in Simalanggang as OP1 and Rao-Rao as OP2. The OP in migration area is in Kuok Kampar as OP3, and Patapahan as OP4.

Based on the comparison of the use of affixes in the origin area and migration area, there are differences and similarities in the use of affixes among OP. The affixes used in each OP consist of several types, namely 1) prefixes, 2) suffixes, 3) combination affixes (confixes), and 4) combining affixes. The following is the comparison and explanation of each.

\subsection{The Comparison of Prefix}

In comparing affixes, the affix which is used as the basic of comparison is the affix used in general Minangkabau language abbreviated by (GML). Therefore, the basis of the comparison in the explanation of each affix in this article is GML affix. There are several affixes inform of prefixes used in each OP (OP1, OP2, OP3, and OP4), namely the prefix maN-, di-, ta-

Each of these prefixes are found in all research related to isolect. There is no difference in the use of each OP are found after being compared. It means, all OPs in the area of origin and migration area use the same form of affixes. Example:maompeh'mengempas'; ditanak 'dimasak', dijaik 'dijahit', tacokiak 'tercekik', tagantuang'tergantung', tagayuik 'tergayut', babuRu 'berburu', bajalan 'berjalan', and baRanang 'berenang'.

\subsection{The Comparison of Suffix}

There are three affixes in forms of suffixes are used in each OPs. Those affixes are suffixes $-k a n,-a n$, and $-i$. There are some differences and similarities in the use of suffixes in each OP's after being examined. The descriptions on each of them are as follow.

\subsubsection{The Comparison of Suffixes kan-}

There are differences and similarities in the form and use of suffix in Minangkabau and migration area. There are three variations of suffix in OP3 and OP4. The difference is in suffix -kan in GML. In OP3 and OP4 the forms of in, eng, and ong tend to be used. Examples of its use are idui?in, 'hidupkan' 'turn on', abihin, 'habiskan' 'spend', ange?eng, 'panaskan 'heat up', lolo?ong, 'tidurkan' 'sleep'. Each of these affixes (in-, eng, and ong) functions as an 
imperative/command affix. All these affixes polymerfemis words mean to order or command the speech partner to do something according to the demands of the verb in question. Meanwhile, in OP1 and OP2 suffix -kan is variant with -an. Example abihan 'habiskan' (spend it), ange?an 'panaskan, (heat it) laloa?an 'tidurkan', (Sleep) itaman 'hitamkan', (Blacken) lapangan, 'lapangkan' (Spread it), kosongan 'kosongkan', (empty) abiha 'habiskan', (Spend it) dudu?an 'dudukkan',(sitting) minuman 'minumkan',(drink it) and kiriman 'kirimkan' (send it).

Each of these suffixes also serves as an imperative affix, because all words ended in -an mean to give a command. The word itaman 'hitamkan' has a grammatical meaning "to be black" (command). Likewise with the word lapangan 'lapangkan', duduakan, 'dudukan', andabihan, 'habiskan' has grammatical meaning that is command or order, 'to be roomy ',' make it empty ',' make it out ',' make it sit ', and' make it run out '

\subsubsection{The Comparison of Suffix-an}

There is no difference in the form of each study ofisolect are found in the use of suffix an. The suffix -anin GML, in four researches of isolect (OP1, OP2, OP3, and OP4) also used the form -an. Examples: minuman, aliRan, aliran, jaitan, musiman, asinan and kataguRan.

\subsubsection{The Comparison of Suffix- $i$}

Similar to suffix -kan, suffix $-I$ used in GML in OP3 is variant with in- and -eng. Examples: aliRin 'aliri', bungkuihin 'bungkusi', abihin 'habisi', and ange?eng 'panasi'. These suffixes are used in form $-i$ in $O P 1$ and $O P 2$. The examples as follow, kirimi 'kirimi', abihi 'habisi', rato?i 'ratapi', tangihi'tangisi', lupoi 'lupai', guloi 'gulai', suo?i'suapi', and rato? i ratapi'.

\subsection{The Comparison of Confixs}

There are several confixes used in OP1, OP2, OP3, and OP4. The confixes are peN-an, $b a-a n$, and $k a-a n$. Each OP uses the same form, by mean there is no difference between each $\mathrm{OP}$ in the use of confix. Example: pangabisan 'penghabisan', pandongaRan 'pendengaran; batangihan, balupoan, bajauahan; kasaki?n, katakui?an, dan kaitaman.

\subsection{The Comparison of Joining Affixes}

There are several joining affixes used in each study of isolect. The researcher finds the differences in the use of joining affixes between isolect in migration area and in the origin of area after comparing among the isolects are done. Joining affixes used in the area of origin (OP1 and OP2) cover the joining affixes me-kan, di-kan, mei-i, and di-i. However, several differences are found in migration area (OP3 and OP4). Following are the explanation.

\subsubsection{The Comparison of Joining Affixes ma-ka}

Based on the comparison of joining affixes ma-kan among the isolect, there are several differences in the use of joining affixes ma-kan which are used in in GML. In OP3 the form of joining affixes use are ma-an and ma-in. For example, manyuoa?an 'menyuapkan',mandongaRan 'mendengarkan', mamandiin 'memandikan', mambungkuihin 'membungkuskan', and mangirimin 'mengirimkan'. In OP4, the form ma-kan and ma-in are used. Example: manyuo?kan, mandangakan, mamandiin, and mambungkuihin. Meanwhile in 
OP1 and OP2, the form ma-kan is used ma-an. Example: mamasua?an 'memasukkan', mamandian, 'memandikan', mandangaan 'mendengarkan', mambalian 'membelikan', andmambacoan 'membacakan'.

\subsubsection{The Comparison of Joining Affixes di-kan}

Similar to affix ma-kan, the differences in use is also found between OP3 and OP4 with OP1 and OP2. Affix di-kan in GML on OP3 is realized in the form of di-kan and di-in. Example: disuoa?an, didongaRan, dimandiin, dibungkuihin, dikiirimin. In OP4 the form of di-kan and di-in are used. Example: dibarasihkan, dibalikan, dimasukan, dimandikan, didongakan, dimandiin, dibungkuiin, dikirimin. The form of di-an is also used in OP1 and OP2, such as dimasua?an, dimandian, didongaan, dibalian, dibacoan, and ditulihan.

\subsubsection{The Comparison of Joining Affixes $m a-i$ dan $d i-i$}

Based on the comparison of the use of joining affixes $m a-i$ and $d i-i$, there is no difference in the use of joining affixes of isolect in migration area (OP 3 and OP4) and the isolect in the origin of area (OP1 and OP2). This is meant all of OPs (OP3, OP4, OP1 and OP2) use similar joining affixes. Example: menyaki? $i$, malukoi, malupoi, maange? $i$, mambacoi, and mangguloi. The passive form are disaki? $i$, ditakui?i, dilukoi, dilupoi, diange? $i$, dibacoi, and diguloi.

From the comparison above, it appears that there is a similarity between isolect in the origin of Minangkabau language and the migration region. This similarity shows that traces of Minangkabauness still exist in migration area. The history records that the observation points in the migration area are the area of the Minangkabau people who used to be. The area then developed into a village of Minangkabau people by some of nomads who decided to stay and establish a village there [16]. Differences in affixes among isolect in the two regions can be understood because these migration regions are now included in Riau Province, whose people speak Malay.

\section{CONCLUSIONS}

There are several things can be concluded after comparing the forms and the use of affixes in the origin of minagkabau language and migration area. There are differences and similarities in the form use of affixes between the area of origin and migration region. Differences in the form and use of affixes are commonly found in the form of suffix and joining affixes. The similarity in form and use of affixes are commonly found in the form of prefixes and confixes.

\section{REFERENCES}

[1] M. Ramlan, Morfologi Suatu Tinjauan Deskriptif. Yogyakarta: CV. Karyono, 1987.

[2] Abdul Chaer, Morfologi Bahasa Indonesia: Pendekatan Proses. Jakarta: Rineka Cipta, 2015.

[3] A. Zainal and Junaiyah, Morfologi: Bentuk, Makna, dan Proses. Jakarta: Gramedia, 2009.

[4] Es Zeli, “Afiks Derevasional Bahasa Minangkabau Dialek Kamang Magek,” 2016. [Online]. Available: http://jom.unri.ac.id/index.php/JOMFKIP.

[5] Riska Rahmadhana, "Prefiks dalam Bahasa Minangkabau Dialek Agam," 2014. 
[Online]. Available: blogspot.com.

[6] Noviatri, "Afiks -an dalam bahasa Indonesia dan Bahasa Minangkabau," in Bahasa, Sastra, dan Seni, 2014.

[7] et al Jaafar, "Morfosintaksis Dialek Negeri Sembilan dan Dialek Minangkabau," Gema Online J. Lang. Stud., vol. 17, no. 2, 2017.

[8] Noviatri dkk, "Affixes of Minangkabau Language in The Origin and Rantau Area: Study of Morphological Variation," Arbitrer, vol. 4, no. 2, 2017.

[9] Reniwati, Noviatri, and Aslinda, "Bahasa Minangkabau di Daerah Asal dengan Bahasa Minangkabau di Daerah Rantau Malaysia: Kajian Dialektologis," Arbitrer, vol. 3, no. 2, 2016.

[10] Aslinda, Noviatri, and Reniwati, "The Trace of Minangkabau-Wise in Malaysian Language," PPM-UKM, vol. 2, no. 7, 2015.

[11] M Yusdi, "Affix ter- in Indonesian: A Language Description," in International Seminar On Linguistics, 2017.

[12] Yulino Indra, "Kesalahan Afiksasi Bahasa Indonesia Murid-Murid SD di Kabupaten Agam," Salingka, vol. 11, no. 1, 2014.

[13] Umi Kulsum, "Suffix -Is and -Ik and Its Problematics nn Indonesian Language," Metalingua, vol. 13, no. 2, 2015.

[14] Nadra and Reniwati, Dialektologi: Teori dan Metode. Yogyakarta: CV Elmatera Publishing, 2009.

[15] Sudaryanto, Metode dan Aneka Teknik Analisis Bahasa:Pengantar Penelitian Wahana Kebudayaan secara Linguistis. Yogyakarta: Sanata Dharma University Press, 2015.

[16] Gusti Asnan, Dunia Maritim Pantai Barat Sumatera. Yogyakarta: Ombak, 2016.

[17] K. Saddhono and D. Sulaksono, "Indoglish as adaptation of english to Indonesian: change of society in big cities of Indonesia." IOP Conf. Ser.: Ear. and Envi. Sci.. vol. 126 no. 1 IOP Publishing, 2018. 